\title{
Flexible Corporate Social Responsibility: Evidence from A Chinese Company in Africa
}

\author{
Yang Jiao ${ }^{1}$ \\ Miami University
}

In the emergent field of corporate social responsibility (CSR) studies, there has been growing interest in understanding and practice in particular sociocultural contexts in developing countries. As a rising force of overseas investment, Chinese enterprises are increasingly encountering local challenges stemming from CSR. This paper is an ethnographic study of a Chinese gold mining company in contemporary Ghana in regard to CSR knowledge and practice. It investigates how multiple actors negotiate understandings of CSR in a Chinese gold mining company as compared with an American gold mining company. The research was conducted near the mining sites located in Odumase of Eastern region and Juaso of Ashanti region of Ghana during 2016. Its CSR practice was compared with that of the Akyem mining site operated by an American mining corporation. Through ethnographic fieldwork, this paper contextualizes the construction of diverse understandings of CSR among multiple actors in this Chinese investment project. It also demonstrates how both formal and informal engagements with affected communities constitute its CSR practice. Based on a case study and comparison with an American mining company, this paper finds that large-scale Chinese mining operation in Africa is receptive of the concept of CSR but its practice is very unique.

\section{INTRODUCTION}

The last two decades have witnessed China's rising profile as a global investor especially in the developing world. From its "Go Global" (zouchuqu 走出去) strategy to the most recent Belt and Road Initiative, China has audaciously embraced globalization and mercantilism. Against such background, Chinese enterprises and entrepreneurs encounter the culturally "other" around the globe through investments and trade on an unprecedented scale.

China's foreign direct investments (FDI) to Africa have been growing at an unprecedented rate with its total FDI stock in Africa reaching US\$39.88 billion in 2016 (MOC, 2016), more than twelve times of that in 2004. Although only Africa received about $2.9 \%$ of China's total FDI, the substantial growth in the new millennium reflects that the continent has been one of the most popular FDI destinations for Chinese companies. The three largest sectors of China's FDI to Africa are construction (28.3\%), mining (26.1\%) and manufacturing (12.8\%). Chinese investments in Africa's mining sector are particularly active when compared with its global FDI profile with only $11.2 \%$ going to mining (MOC, 2016). Although Chinese investment in Africa's mining sector has grown more vigorously during the past decade than that from the US, China is still a relatively new player. Mining accounts for $66 \%$ of US total FDI stock in 2015 (Eom et al., 2017). 
A major challenge to Chinese enterprises in overseas investment is adapting to the social, cultural, legal, and political environment. In extractive industries such as mining, challenges are most arresting since operations usually cause concerns about significant social change in affected communities. Chinese companies usually face challenges from multiple stakeholders at the local level who are seeking alternative sources of income, compensation for affected land, relocation of housing, and environment reclamation, all of which should be addressed by corporate social responsibility theories and practices. In addressing these challenges brought by China's global investments, enterprises are still exploring paths and theories of corporate social responsibility for their own unique problems. In 2012, China for the first time published the Guide on Social Responsibility for Chinese International Contractors (Ministry of Commerce\&China International Contractors Association, 2012). While the Chinese government recognizes the crucial importance of CSR for its overseas investments, this guideline is written for construction and civil engineering companies and does not provide standard CSR benchmark for diverse industries. As a result, successful investments usually apply an ad hoc approach in their CSR practiceslocally and achieve a hybrid form of existence within the local contexts.

Many Western scholars have focused on the implications of Chinese FDI in developing countries from the perspective of Western legal and social frameworks. For example, analyses of Chinese presence in Africa express concerns of poor labor conditions, environment degradation, and corruption. Notwithstanding these existing issues, these analyses have failed to investigate such processes via a bottom-up approach, and therefore miss the idiosyncratic conditions and diverse factors contributing to the Chinese experience regarding the social, cultural, and political implications of FDI. The anthropologists have focused on labor issues (Lee, 2007), manager-employee relationship (Giese 2010), and corruption (Kragelund, 2009). Corporate social responsibility (CSR) of Chinese enterprises is one of the least discussed areas among studies of China-Africa engagement.

Most of the scholarship on CSR is addressed in management studies. Management literature focuses mostly on the level of corporation and formal market. However, economic anthropologists have long argued that economic behavior is not mere rational choices but is embedded in other social institutions as well. CSR practice as corporate behavior is also embedded in wider social, cultural, and institutional contexts that involve both formal and informal actors. When studying CSR in developing countries, conceptual models and methods that are used to study corporations in formal market economies are no longer adequate to capture the complex processes in which CSR is expressed and practiced by multi-level actors in various formal and informal institutions (Jamali and Karam, 2016). Furthermore, CSR is co-constructed via negotiation among actors from both business and non-business contexts. Thus, CSR expressions and practice can benefit from the holistic approach and micro-focus of anthropological approaches that examine at the level of actor practice.

Business and development anthropologists have started to join the table to contribute its methodology and theories. In the field of CSR, anthropologists have offered insights on how CSR is articulated and realized through on-the-ground case studies in many sectors (Dolan and Rajak, 2016). In particular, scholars have investigated specific practices of CSR and responses in local contexts around the world (Sawyer, 2004; Kirsch, 2006; De Neve, 2009; Dolan and Scott, 2009; Li, 2010; Gardner, 2012; Gilberthorpe, 2013). These contributions pave the way for further theorization of CSR in diverse socio-cultural contexts in which both corporations and local communities operate.

While studying CSR in contexts of developing countries, anthropologists have a special duty, which is to construct a CSR theory inductively based on their fieldwork rather than to interpret findings in terms of theories in Western market economy contexts. The conceptual framework of CSR formed in the Western contexts has been imported to China since the 1990s (Moon and Shen, 2010). In the recent wave of outward investments, many Chinese businesses fail to meet local CSR expectations, which results in controversies and losses. With a late exposure to this imported construct, entrepreneurs and CEOs of Chinese corporations become increasingly aware of its importance during their OFDI operations. In response, the Chinese government has put forward regulations regarding CSR activities (Yin and Zhang, 
2012). However, CSR awareness among most managers and CEOs is still limited. Many are not cognizant of CSR international standards (Xu, 2010). State-owned enterprises, large-scale enterprises and companies that are traded in the stock market practice CSR more assiduously. Thus, it is crucial to understand how CSR is understood and practiced by Chinese corporations within a particular local context.

This paper aims at adding to the existing anthropological scholarship of CSR by providing a specific case study of CSR practice of a Chinese mining corporation in Ghana. By examining attitudes and practices by various Chinese and African actors, it aims at identifying a CSR construct with Chinese characteristics and its implications against the backdrop of China's prominent profile in Africa. This paper also contributes to CSR literature on developing countries by joining discussions about fieldwork-based localized CSR theory. This paper hopes also to contribute to business anthropology scholarship on Chinese OFDI by identifying challenges of Chinese enterprises investing overseas.

This paper is based on ethnographic fieldwork conducted in the Odumase, Juaso, and Akyem (Figure 1), all of which are towns near the mining sites, as well as Accra, Ghana in 2016. Participant-observation and semi-structured interviews were conducted with the chief geologist, community program manager, Chinese project manager, and CEO of a Chinese gold mining company. Semi-structured interviews were also conducted with local chiefs, opinion leaders, members of social responsibility forum near the mining sites. Interviews were also constructed in Accra, with chief technological officer of the Ministry of Lands and Natural Resources and staff members of Ghana Minerals Commission.

\section{FIGURE 1}

\section{MAP OF FIELD SITES (FROM LEFT TO RIGHT: JUASO, AKYEM, ODUMASE)}

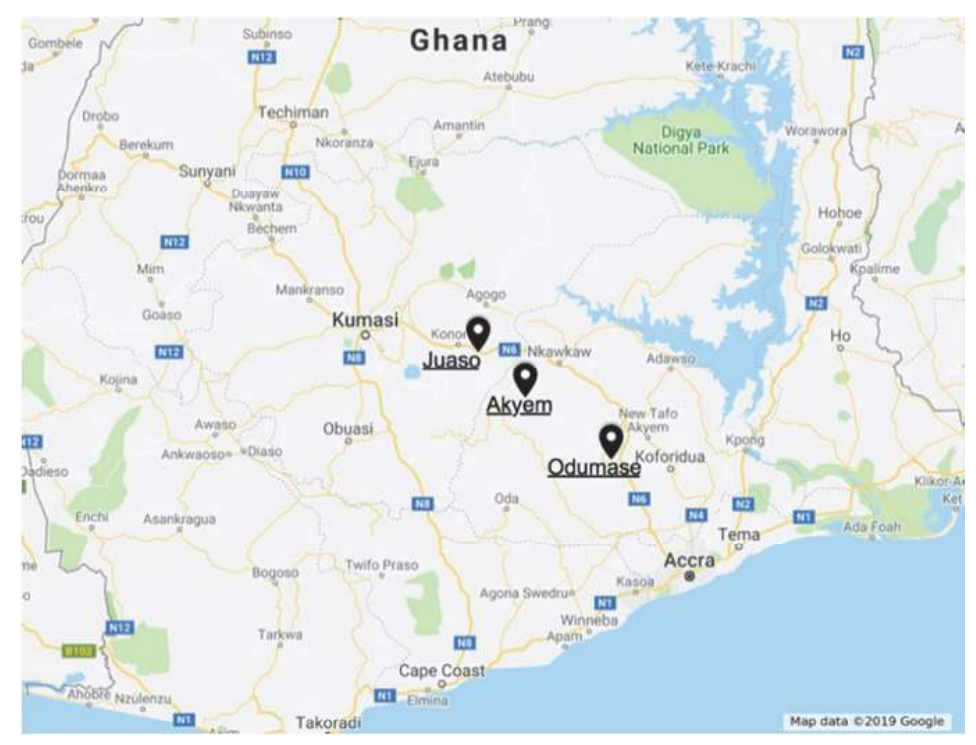

\section{Ghana's Gold Mining Industry and Chinese Investments}

Ghana is considered as a strong democracy in West Africa and model example of neoliberal reforms. Following the unsuccessful socialist configuration of its economy envisioned by Kwame Nkrumah in the 1950s and 1960s, Ghana has fully embraced neoliberal principles and has become a major hub economy led by export-oriented growth in the West African region (Aryeetey and Harrigan, 2000).

In the 1980s, Ghana initiated structural adjustment programs prescribed by the World Bank and International Monetary Fund in an effort to recover from domestic agricultural crisis and an international debt crisis (Rothchild, 1991). Without a full-fledged industrial base, Ghana is deeply locked in its foreign 
trade agreements mandated by its lenders and thus heavily relies on exporting its natural resources such as gold, timber, minerals or food stuffs like cocoa and shea nuts (Chalfin, 2004).

In the mining sector, these policies include divesting state gold mines, rehabilitation of existing mines, liberalization of exchange rate, and implementing attractive policies and legal, fiscal, and institutional framework for the minerals sector. Such policy changes have resulted in an increase of gold production from 240,000 ounces in 1984 to $4.4 \mathrm{mn}$ ounces currently. The minerals sector contributes $16 \%$ of the domestic revenue. Total investment inflow into the sector since 1983 is 15 billion USD. (Speech by the Minister of Lands and Natural Resources, Nii Osah Mills, 2016)

In the mid-1990s, Ghana furthered its effort to integrate itself into the world economy when the Trade and Investment Gateway initiative was put forth, paving the way for its position as an economic hub for the West African region (Chalfin, 2004). Efforts such as tax-free industrial zones and seeking aid for transport infrastructure aiming at increasing foreign investments and making Ghana an attractive gateway for foreign capital.

Around the same time, China has been experimenting on its own market reform since the 1980s. China's investment in Africa dramatically intensified since 2000 and its aid programs in Africa also took a new turn to emphasize win-win relationship with recipients. Facilitated by the "Go Global" strategy designed by Chinese government that encourages Chinese companies to internationalize and invest in foreign markets, many Chinese state-owned companies used foreign aid projects as stepping stones to establish themselves and expand to other sectors. Private sector capital and state-owned company join resources to take advantage of neoliberal policies on both sides, contributing to increasing Chinese presence.

The Chinese footprint in Ghana's gold mining is relatively new as compared to Western countries such as UK, U.S.A and Australia. The earliest Chinese gold mining prospecting in Ghana took place in the late 1980s when a group of geologists from Heilongjiang province visited there. There is no official data available on the number of Chinese-owned gold mining companies in Ghana. According to Chinese Embassy in Ghana, only a few Chinese corporations have proper licenses to operate in Ghana in 2016.

These Chinese companies have only obtained reconnaissance or prospecting licenses. The reconnaissance license can only grant limited reconnaissance operations for an initial period of twelve months. The prospecting licenses grant operations for three years (Ghana, 2006). According to data obtained from the Minerals Commission, only five Chinese companies are among the list of companies granted mineral rights in 2016. Of these five, the Chinese company in this paper is the only one that has obtained mining lease rights (see Table 1). 


\section{TABLE1 \\ LIST OF CHINESE GOLD MINING COMPANIES REGISTERED WITH MINERALS COMMISSION}

\begin{tabular}{|l|l|l|l|l|}
\hline $\begin{array}{l}\text { Name of } \\
\text { Company }\end{array}$ & Size $\left.\mathbf{( k m}^{\mathbf{2}}\right)$ & Location & Region & Category $^{2}$ \\
\hline $\begin{array}{l}\text { CJIC-China } \\
\text { International } \\
\text { Investments Ltd }\end{array}$ & 5.67 & Wassa Dunkwa & Western & $\mathrm{F}$ \\
\hline $\begin{array}{l}\text { Guanhua Mining } \\
\text { Investment } \\
\text { Ghanaian Ltd }\end{array}$ & 25.51 & Kutukrom & Western & $\mathrm{F}$ \\
\hline $\begin{array}{l}\text { Hubei Yangtze } \\
\text { International } \\
\text { Mining Co. Ltd }\end{array}$ & 51.02 & Yawkrom & Western & $\mathrm{F}$ \\
\hline $\begin{array}{l}\text { Shaanxi Mining } \\
\text { Gh. Ltd }\end{array}$ & 300.52 & Kulungugu & Upper East & $\mathrm{F}$ \\
\hline $\begin{array}{l}\text { Akoko Goldfields } \\
\text { Ltd }\end{array}$ & 28.07 & $\begin{array}{l}\text { Wirenkyiren } \\
\text { Amanfroo }\end{array}$ & Eastern & $\mathrm{AX}$ \\
\hline
\end{tabular}

Source: List of Companies that have been granted mineral rights as on January 12, 2016. Minerals Commission.

In addition to these officially registered large-scale Chinese companies, it is estimated that thousands of Chinese nationals operate in small-scale surface gold mining, which is prohibited for foreign nationals by Ghanaian law. As a result, the Ghanaian law enforcement agencies frequently arrest individual Chinese miners for violating mining regulations and immigration laws. The Ghanaian enforcement has led numerous crackdowns on illegal small-scale mining since 2009. The presence of small-scale Chinese gold mining triggers conflicts with Ghanaian artisanal miners as well as concerns of local community regarding environment.

\section{The Policy Environment of Gold Mining and CSR}

Although foreign nationals are prohibited to operate in small-scale gold mining, Ghana does have a regulatory framework for gold mining operations by large-scale corporations. The policy environment in which these enterprises are to operate not only consists of national laws, policies, guidelines, but also includes customary system of governance at the local level such as community stool land ${ }^{3}$ management by chiefs.

The laws governing all minerals and mining activities include Ghana's Minerals and Mining Act (703), Minerals and Mining (Amendment) Act (794), and Minerals and Mining (Amendment) Act (900). As an addition to ensure mining sector's contribution to sustainable development, Ghana recently launched Minerals and Mining Policy (Ghana 2016). Two highlights of the new policy are: 1. to regulate small-scale mining to be environmentally responsible, and 2. to ensure the integration of the mining industry with the local economy, especially the service sector.

From the perspective of government regulatory body, mining corporations need to meet requirement in the following areas: 1 . the licensing of mineral and mining operations; 2 . environmental regulations; 3 . occupational health and safety; 4. fiscal policy attracting investments; 5. consultation with affected stakeholders and community development. 
Ghana's Minerals Commission provides a more detailed guideline for CSR (Minerals Commission, 2012). The ten themes of the guidelines include: corporate governance and ethics, human rights, workplace and labor standards, health and safety, environmental stewardship, risk assessment and management, material and supply chain stewardship, community and social development, stakeholder engagement, and compliance and reporting.

\section{A Chinese Gold Mining Company's CSR Practice}

In his fifty's, Mr. L has been an entrepreneur in Ghana for over a decade. Originally from Zhejiang province, Mr. L had worked in many sectors before becoming an agricultural chemicals businessman in Ghana, selling pesticide and farming equipments from his Kumasi-based company. When the gold price had picked up around 2008, he saw opportunities in the gold mining and started a transition towards mining sector. In 2009, he persuaded an agricultural products and trading company from his hometown to acquire his Ghanaian company and became the CEO. The new company became a subsidiary of the Hong Kong listed holding company and Mr.L was able to pool capital to acquire $83 \%$ share of a Ghanaian mining company having mining rights on a 28.07 square kilometers concession and reconnaissance permit for 56.13 square kilometers in East Akim District of the Eastern Region. Thus, Mr. L's new mining company became the only Chinese controlled mining company that has been granted mining lease license.

As a savvy entrepreneur, Mr. L is familiar with the policy environment of gold mining and adept at navigating through complex relations with regulatory agencies, Ghanaian business partners, and local chiefs. He is well aware of the social impacts of gold mining and risks of small-scale artisanal mining. Thus, he chooses to invest in large-scale gold mining by cooperating with large Chinese mining corporations that have extensive experience.

In 2014, Mr. L's GS Mining company started to have partnership with a Chinese state-owned geological exploration company, JS geological service, to conduct reconnaissance at concessions near Odumase of Eastern region and Juaso of Ashanti region. In 2014, GS mining decided to first engage in surface mining at its Odumase site.

The Odumase community first opposed the mining operations, assuming it would pollute the Dansu river and farmers were also unwilling to give up their land where they grew crops such as cocoa requiring long-term cultivation. Local farmers also expressed concerns since surface mining operated elsewhere by small-scale miners from Guangxi, China caused serious environmental degradations. The local chief, the regional chief of Kibi, farmer representatives, opinion leaders, and assemblywoman all showed concerns. Thus, GS mining hired two Ghanaians, $\mathrm{S}$ and $\mathrm{M}$ as community relations officers to consult with all affected stakeholders. GS mining invited them to meet and explain their proposed work.

By relying on local talent, GS was able to connect with local stakeholders without language barrier. S has extensive working experience in gold mining companies and had worked for the Ghanaian mining company GS acquired for four years. M had worked for an Australian gold mining company called Pesos Mining before joining GS. After several meetings with stakeholders, GS mining finds all the affected farmers and explained in detail how the mining would be carried out. Then, $\mathrm{S}$ and $\mathrm{M}$ invited stakeholders to form a compensation committee for the Odumase surface mining operation and hold meetings to discuss compensation terms. The local chief on behalf of the compensation committee of the affected community agrees on compensation terms. Then, $\mathrm{S}$ and $\mathrm{M}$ invited land evaluation officer from Korforidua to survey affected farmland and meet with affected farmers to discuss total compensation for their crops (see Table 2). 
TABLE 2

AMOUNT COMPENSATED TO FARMERS AFFECTED BY GS MINING COMPANY'S PHASE IV OPERATION

\begin{tabular}{|l|l|l|l|}
\hline Affected Farmers & Crop compensated for & Acre & Amount (Ghc) \\
\hline 1 & Cocoa & 1.0 & 7,500 \\
\hline 2 & Maize, Freeland & 3.17 & 14,137 \\
\hline 3 & Cocoa & 0.35 & 2,625 \\
\hline 4 & Cocoa & 0.31 & 2,325 \\
\hline 5 & Cocoa & 1.0 & 7,500 \\
\hline 6 & Cocoa & 1.4 & 10,500 \\
\hline 7 & Pepper & 0.2 & 750 \\
\hline 8 & Maize & 1.15 & 4,312 \\
\hline 9 & Cocoa & 0.3 & 2,250 \\
\hline 10 & Freeland & 1.0 & 3,750 \\
\hline 11 & Maize & 0.66 & 2,475 \\
\hline 12 & Maize & 0.2 & 750 \\
\hline 13 & Cocoa & 1.5 & 11,250 \\
\hline 14 & Freeland & 2.5 & 9,375 \\
\hline
\end{tabular}

Source: Golden Sunshine Ghana Ltd.

In addition to crop compensation, the compensation committee asks for a new main palace for the chief, a primary school, scholarships for students, a public market structure, public restrooms, as well as a new clinic. According to the Odumase local chief and a former assemblywoman, they initially had concerns, but were glad that $\mathrm{S}$ and $\mathrm{M}$ used the compensation committee as a platform to explain the process and negotiate compensation terms. These were established CSR models practiced by Western mining companies such as Newmont. Most importantly, the land was reclaimed after the mining operation. It is S and M's prior CSR knowledge and practicing experience that enabled the Odumase surface mining to go smoothly.

The main issue during compensation process is the identification of real owners of affected land. Farmers as tenants of the land are also compensated to an agreed amount between the owners and GS mining. Another obstacle during negotiation with farmers is related to the seasonal feature of agriculture. Some of the affected area is in strip lands near the river. In such strip lands, one end is on the hilly side while the other is close to the Dansu river. Farming lands are organized this way because in the dry season irrigation is easier. Thus farmers grow vegetables that need continuous irrigation in such strip lands. Cocoa plants need about 7 to 8 years before it can yield satisfying quality beans. Therefore, for farmers who have just started their batch of cocoa, it is emotionally difficult for them to lose the opportunity to see the harvest even if they get compensated. Sometimes, when the mining work approach the affected land which has been already compensated for, farmers still have to be persuaded again because it is close to harvest time. "They have a deep attachment to their crops and we have to take that into account," commented by S, who also own land elsewhere. S and M were quite sensitive to such issues since they have family members who are farmers. 
It is interesting to note that according to Mr. L, CEO of GS mining, compensation seems to mean concrete things such as money, a clinic or a school building. However, what $\mathrm{S}$ and $\mathrm{M}$ have faced during the compensation process calls for a more comprehensive plan that takes into consideration the seasonal feature of agriculture and farmers' emotional attachment to their hard work and way of life. Affected farmers can reduce their loss, both economic and psychological, from the mining operations if it is coordinated with farming seasons. Farming knowledge and experience enabled $\mathrm{S}$ and $\mathrm{M}$ to communicate with affected farmers and manage mining work more effectively. $\mathrm{S}$ also takes some farmers to other proper mining sites in farming areas to observe how proper mining is conducted. These farmers come back to educate other farmers and to ensure them the reclamation procedures can still return the land to a good condition.

Therefore, $\mathrm{S}$ and $\mathrm{M}$ are instrumental in realizing CSR themes regarding environmental stewardship, risk assessment and management, community and social development, as well as stakeholder engagement. Their local expertise and prior work experience are the core assets for GS mining's CSR practice. However, this does not mean that Mr. L and other Chinese actors in GS mining have the same understanding of CSR.

\section{Newmont Ghana's CSR Practice}

Newmont Ghana Gold Limited (NGGL) has been operating as a leading foreign controlled gold mining company in Ghana for more than ten years. NGGL has two major mining sites: the Ahafo site and the Akyem site. The Ahafo mine is located in the Brong Aharo region and is Newmont's first African site. The Akyem site is newer and located in the Birim North District of the Eastern Region. NGGL incorporates CSR in its corporate governance by adhering to the IFC Performance Standards in terms of Environmental and Social Responsibility Practices.

In order to include the community into the economic gains led by mining, NGGL established the Community Development Unit. The initiatives undertaking Community Development Unit include local business opportunities, infrastructure projects and educational programs. In addition, NGGL helped the affected community to establish NADeF, thus enabling and supporting community initiated development programs.

Field visits to the Akyem mine affected community find a range of community development efforts by NGGL. The Akyem mine local community and NGGL reached a social responsibility agreement, which stipulates how NGGL's growth could enkindle the growth of local community. Community development programs that Newmont has already implemented are: 1. a new primary school; 2. scholarship for students from all ten affected communities; 3 . traditional festivals are funded; 4. micro-financing program for people in need; 5. two acres of land, fertilizer, crop seeds are provided to affected farmers for five years; 6. resettlement community called Yayaso is completed for one affected community; 7. water sanitation projects; 8 . new roads running through the town and a tunnel bridge over which Newmont vehicles used to access the mining site. The funding for these projects comes from the Community Development Foundation, which reserves $1 \%$ of profit of the gold produced by Newmont.

Since Akyem started commercial production in 2013, several issues have been concerns for local community members. First, using dynamite has affected families. Second, the mining operations boost the service sector in Akyem - resorts, restaurants, and hotels have opened-but the cost of living has risen as well. Third, crime rate has increased. All of these concerns are discussed at the Social Responsibility Forum.

\section{Flexible CSR practice in Chinese Context}

Despite the different development stages of GS mining and NGGL, what is unique about a Chinese mining company's CSR awareness and practice?

Chinese corporations grow in a context that business-to-government guanxi plays an important role in affecting the performance of a corporation (Braendle et al, 2005). According to Mr. L, corporation is for 
profit and does not need to put much effort in the community and society, especially at its early development stage. Though Chinese corporations become more aware of CSR, they are exercising such responsibilities as a proxy to fulfill government requirements. According to a survey conducted by Xu (2014), Chinese managers' understanding of CSR consists of the following unique dimensions: employment advancement, business ethics, and social stability. With such vague understanding in mind, Chinese managers and CEOs, especially those of state-owned enterprises, are not actively seeking to incorporate CSR in its operations at their own. They are more familiar with reporting to government guidelines than negotiating with stakeholder and community. When operating overseas, such CSR understanding is brought to investment destinations and many Chinese corporations over-simplify CSR as a way to build and report good public relation with the local community and compliance with government guidelines.

Based on the case study of GS mining, CSR awareness is comprised of multiple components from various Chinese and Ghanaian actors within the company. First, Mr. L, as a well-established entrepreneur in Ghana, is aware of CSR guidelines listed by the Minerals Commission. However, he believes that only full-fledged businesses can afford to comprehensively integrate CSR into corporate governance. Here, CSR as a construct means something that his company offers back to the community in concrete forms, such as donation of a primary school building or a drilled well for local village. He prioritizes government regulation bodies and individuals in power positions in operating his mining business. These include government bodies such as MLNR, Minerals Commission, local chiefs at the concession, and other local systems of governance. This is informed by Chinese business culture that focuses on guanxi management with government. On the other hand, local employees, affected farmers, and other community members are not prioritized and are considered as "people who need to be dealt with".

Second, S and $\mathrm{M}$ are Ghanaian employees who offer local expertise for project operations including issues concerning community relations. Their background and previous CSR knowledge and experience facilitate GS mining in fulfilling certain CSR aspects including stakeholder engagement, community and social development, and environment stewardship. S and M borrow CSR practice they obtained from past employers and carry them out on an ad-hoc basis as they become necessary during mining operations. Although CSR is not an integral component of GS mining's corporate governance system like the case of NGGL, local expertise and ad-hoc practice enable GS mining to fulfill some social responsibilities during its early stage. As a local opinion leader commented, "I hope GS mining continues to learn from CSR practice of NGGL."

Third, Chinese geological staff and managers are not familiar with CSR concept but perform certain aspects in their daily duties. This is most evidently demonstrated in their daily work and engagement with local employees, community members, and other Ghanaian actors. Mr. $\mathrm{J}$ is a young technician in charge of reconnaissance job for GS mining. At the workplace, one of the biggest challenges for him is to manage Ghanaian employees who are often late for work or idling during work. He got the local chief to persuade them to accept wage settlement by contract rather than by day. This has changed their work performance. Mr. J also carried out CSR by engaging local stakeholders and fulfilling compliance. The work visa of geological staff is applied in the name of GS mining, partner of JS geological service, which results in the inconsistency between the work visa of the geological staff of JS and GS mining that hold the account. To solve this issue, Mr.J consulted with GS mining, cultivated guanxi relations with various Ghanaian governing bodies including Ghana Immigration Authority and Minerals Commission, and finally solve the problem of opening new accounts for JS geological service.

According to Ghana Minerals Commission's CSR guidelines, CSR consists of ten areas. Based on the case study of GS mining, the most relevant CSR themes are workplace and labor standards, environmental stewardship, risk assessment and management, community and social development, stakeholder engagement, and compliance and reporting. Compared with NGGL, GS mining does not have an integral corporate office in charge of CSR in its mining operations, nor does it have a permanent organizational platform for local stakeholders to govern and discuss community development. However, 
GS mining does perform CSR on an ad-hoc basis and is inclusive of anyone who is directly relevant with corporate operations. From the perspectives of CEO, local community relations officers, and geological technician and manager, CSR is practiced in tandem with operation goals via their engagement with stakeholders. But there is lack of a unified understanding of CSR.

\section{CONCLUSION}

During the past decade, there has been growing interest in CSR practice in developing countries. Although most CSR scholarship is contributed by management field, anthropologists who are interested in business organizations and the ethical aspects of corporate behavior also join the discussion. The anthropology of CSR has made unique contribution to the field by studying how CSR is understood and practiced in particular socio-cultural contexts and various responses to these practices (Dolan and Rajak, 2016). The uniqueness of anthropological contribution lies in its holistic perspective and ethnographic approach. By shifting focus away from organization and zooming in on multiple actors on the ground, ethnographic findings contextualize particular configurations of CSR awareness and doing.

Based on the case study of GS mining, a Chinese large-scale gold mining enterprise in Ghana, this paper identifies the unique CSR understanding by examining multiple actors: CEO, community relations officers, and geological technician. The comparison with an American gold mining company, NGGL, finds that CSR practice in GS mining is different in three ways. First, the Chinese company lacks a permanent organizational platform for CSR practice and does not have specialized CSR personnel. The practice is on an ad-hoc basis and integrated with corporate operations carried out by various actors. Second, GS mining is open to any actor from either formal or informal context to participate in its CSR practice. There is no fixed definition of the community that requires fulfillment of social responsibility, whereas NGGL gives definition to affected community and draw the line between those included and those excluded. Third, GS mining does not have a unified CSR understanding throughout its corporation, but various actors integrate CSR practice in their daily duties, while NGGL has made CSR a specialized component within its corporate governance system (see Table 3). In short, CSR practice in GS mining is flexible, ad-hoc, and more inclusive of multiple actors. This attests to the understanding that economic activities are deeply embedded in social institutions and various system of governance. 
TABLE 3

COMPARISON OF GS MINING AND NGGL REGARDING CSR PRACTICE

\begin{tabular}{|l|l|l|l|l|}
\hline & Development stage & $\begin{array}{l}\text { Inclusion of } \\
\text { CSR actors }\end{array}$ & $\begin{array}{l}\text { Organizational } \\
\text { support }\end{array}$ & CSR practice \\
\hline GS mining & $\begin{array}{l}\text { Early; } \\
\text { Reconnaissance } \\
\text { stage }\end{array}$ & $\begin{array}{l}\text { Open to } \\
\text { formal/informal } \\
\text { actors; no } \\
\text { definition of } \\
\text { affected } \\
\text { community }\end{array}$ & $\begin{array}{l}\text { No permanent } \\
\text { CSR support; No } \\
\text { organizational } \\
\text { platform; } \\
\text { Ad-hoc team }\end{array}$ & $\begin{array}{l}\text { Flexible; } \\
\text { integrated with } \\
\text { operations }\end{array}$ \\
\hline $\begin{array}{l}\text { Newmont } \\
\text { Ghana Gold } \\
\text { Limited }\end{array}$ & $\begin{array}{l}\text { Full-fledged; Active } \\
\text { production stage }\end{array}$ & $\begin{array}{l}\text { Clearly defines } \\
\text { affected } \\
\text { community and } \\
\text { exclude other } \\
\text { members }\end{array}$ & $\begin{array}{l}\text { The social } \\
\text { responsibility } \\
\text { forum; } \\
\text { Community } \\
\text { Development } \\
\text { Foundation }\end{array}$ & $\begin{array}{l}\text { Institutionalized; } \\
\text { specialized }\end{array}$ \\
\hline
\end{tabular}

This paper contributes to the study of CSR in several ways. First, this paper offers a specific case of how CSR is practiced in a Chinese company overseas. Ethnographic method and analysis of multi-level actors shed light on the particular socio-cultural contexts. It also provides a comparison with how CSR is practiced in an American company and summarizes its uniqueness. Second, it adds to the discussion of CSR theorization. The study of CSR practice in developing countries requires CSR theory that is built on empirical studies and ethnographic fieldwork. Theories informed by Western market economy contexts are not fit for this purpose.

\section{ENDNOTES}

1. Yang Jiao is visiting assistant professor of anthropology at Miami University. The ethnographic research was funded by a Johns Hopkins SAIS-CARI fellowship (Grant number:

SAIS-CARI-15-03) in Odumase, Juaso, Akyem, and Accra in Ghana. The author is grateful for the support of key informants in Ghana, Mr. L, W, S and M at GS Mining and MLNR chief technological officer and Peter at Ghana Minerals Commission.

2. F refers to foreign-controlled. AX refers to Mining Leases.

3. Stool land refers to land that is managed by chiefs in Ghana. Stool symbolizes power and authority in Ghanaian chieftaincy.Such land has customary or community tenure. 


\section{REFERENCES}

Aryeetey, Ernest and Jane Harrigan.2000. Macroeconomic \& Sectoral Developments Since 1970. In Economic Reforms in Ghana: The Miracle and the Mirage. edited by Ernest Aryeetey, Jane Harrigan, and Machiko Nissanke. London: James Currey.

Braendle, Udo C., Tanja Gasser, and Juergen Noll.2005. "Corporate governance in China-is economic growth potential hindered by guanxi?." Business and Society Review 110, no. 4: 389-405.

Chalfin, Brenda.2004. Shea Butter Republic: State Power, Global Markets and the Making of an Indigenous Commodity. New York: Routledge.

Eom, Janet, Jyhjong Hwang, Lucas Atkins, Yunnan Chen, and Siqi Zhou. "The United States and China in Africa: What does the data say?." SAIS-China Africa Research Initiative, Johns Hopkins University. Policy Brief \#18.

Ghana.2006. Minerals and Mining Act (Act 703).

Gilberthorpe, Emma, and Dinah Rajak. 2017."The anthropology of extraction: critical perspectives on the resource curse." The Journal of Development Studies 53, no. 2: 186-204.

Kragelund, Peter.2009. "Part of the disease or part of the cure? Chinese investments in the Zambian mining and construction sectors." The European Journal of Development Research 21, no. 4: 644-661.

Maignan, Isabelle, and David A. Ralston.2002. "Corporate social responsibility in Europe and the US: Insights from businesses' self-presentations." Journal of International Business Studies 33, no. 3: 497-514.

Minerals Commission 2012. Guidelines for Corporate Social Responsibility in Mining Communities.

Moon, Jeremy, and Xi Shen. 2010."CSR in China research: Salience, focus and nature." Journal of Business Ethics 94, no. 4: 613-629.

Rothchild, Donald.1991. "Ghana and Structural Adjustment: An Overview." In Ghana: The Political-Economy of Recovery. Donald. Rothchild, ed. Boulder, CO: Lynn Rienner.

Sydow, Johanna.2016. "Global concepts in local contexts." In The Anthropology of Corporate Social Responsibility., pp. 217-242. Berghahn Press NY.

Xu, Shangkun, and Rudai Yang. 2010."Indigenous characteristics of Chinese corporate social responsibility conceptual paradigm." Journal of Business Ethics 93, no. 2: 321-333.

Yin, Juelin, and Yuli Zhang. 2012."Institutional dynamics and corporate social responsibility (CSR) in an emerging country context: Evidence from China." Journal of business ethics 111, no. 2: 301-316. 